\title{
Editorial
}

\section{Clementina Acedo}

Published online: 1 October 2009

(C) UNESCO IBE 2009

\section{Prospects: Opening the space for new perspectives and debates}

This second "regular" issue of Prospects could not be more timely, in the context of worldwide education reforms, accompanied by alarming reports on the continuous decline in quality and funding to education-resulting in poorly prepared students and teachers and consequently in what is generally perceived as diminishing the national competitive edge. Included in this issue are articles that bear, directly and explicitly, on the complexity of the current educational landscape, with important topics ranging from the Education for All (EFA) initiative and international assessments to education reforms and their effects on students' and teachers' work. These critical topics, which have come to engage educators as never before, are given full attention in the articles gathered in this issue. More specifically, the articles add substantive arguments to ongoing scholarly debates, by critiquing the EFA as a political strategy; evaluating the sprawling complexity of changes in higher education in countries as diverse as China, India and Russia; comparing the results of the TIMSS and PISA international surveys in mathematics; and analyzing various teacher education reforms in the Asia-Pacific region.

Steve Heyneman starts his Viewpoint with a rapid run through the 19 years since the meeting at Jomtien, Thailand, where the EFA agreements were signed. He describes the history of the EFA initiative to set the context for his own perspective on the EFA as a political strategy. In doing so, he unravels the skein of issues which lie behind a generally positive view of the EFA philosophy and progress. He reminds us that about $17 \%$ of the world's children of primary school age are still out of school, along with $42 \%$ of those at secondary school ages, and that gender disparities in enrollment and completion still exist. Heyneman argues that one major cause of these problems is the weak position of foreign aid-for instance, the low percentage of education lending among the financial commitments of international organizations, the dysfunctional consensus among donor agencies over education as a priority within foreign aid, and, more generally, the stagnation of the education sector development priority for the last twenty years. By considering basic

C. Acedo $(\bowtie)$

UNESCO IBE, P.O. Box 199, 1211 Geneva 20, Switzerland

e-mail: c.acedo@ibe.unesco.org 
education to be the most important priority, the EFA initiative overlooks other sub-sectors and promotes a "one-dimensional view of the purposes of education", a view that has quickly been adopted by the main donor agencies. Thus, Heyneman argues, the EFA has failed as a political strategy. He suggests several steps to correct the problem: development agencies should take a leadership position in promoting a variety of educational priorities; bilateral agencies should play a vigorous role in pioneering "areas in which their countries excel, such as technology and higher education and vocational education and private educational commerce"; and agencies that have specific educational mandates (e.g., UNESCO) need a broader vision that will encourage dialogue among both private and public sub-sectors of education and acknowledge their overall importance.

Philip Altbach offers an insightful overview of the higher education sector in China and India. The "rise" of China and India has lately become an all-absorbing topic for sociologists, politicians and economists alike. The hyper-growth rates of their economies, along with the size of their populations (around one-third of the world's total), are elements that promptly catch the eye of observers. The development of higher education, Altbach argues, is vital to the future economic growth of these two countries. However, it is not only their growth rate, or the size of their growing higher education systems that amazes. Altbach indirectly warns that the expansion of these systems might profoundly disturb their stability. They are faced with unprecedented issues related to funding, educating qualified academics, and building a sustainable academic culture. Also, they are coming under increasing pressure from a budding private higher education sector and the expansion of the state-run one, both internally (e.g., developing masters and doctoral programmes) and externally (e.g., developing international programmes).

Margaret $\mathrm{Wu}$ compares two international surveys that took place in 2003: the Programme for International Student Assessment (PISA) and the Trends in International Mathematics and Science Study (TIMSS). She seeks to identify factors that contribute to discrepancies in their mathematics results. Using country mean scores for 22 countries that participated in both studies, she finds that in general, Western countries performed better in PISA than in TIMSS, while Eastern European and Asian countries performed better in TIMSS than in PISA. However, looking only at country mean scores is in itself a confining factor, as it could lead to confusing interpretations of the results of the two surveys and to possibly incorrect conclusions about students' progress. The author argues that a more comprehensive comparative analysis of PISA and TIMSS data would also include a comparison of item-level data. Above all, the balance of test content and students' years of schooling are significant factors that account for incongruities between the results of the two surveys. This broader perspective provides more information about various strengths and limitations regarding student knowledge and skills in particular countries. Equally important, it could facilitate a review of curriculum and pedagogy, thus making the two surveys more relevant to mathematics education.

Ararat Osipian offers a sustained reflection on the concept of "corruption" in the Russian higher education context. The fall of the communist regime and the emerging market-based economy have provided unparalleled opportunities for corruption-which has become widespread in Russia. On the simplest level, the author uncovers evidence of pervasive corruption in the Russian higher education system, including "bribery in admissions and grading, unauthorized private tutoring, embezzlement, extortion, fraud, nepotism, clientelism, patronage, cronyism, favouritism, kickbacks, cheating, plagiarism, misconduct in research, preferential treatment, sexual and ethical misconduct, transgressing rules and regulations, bypassing of criteria in selection and promotion, ghost instructors, breaches of contract, provision of false information, discrimination, abuse of 
university property, monopolization in academic publishing and distribution of textbooks, misallocation of public resources, and gross waste". But questions remain: What does it all really mean, and how are Russian universities dealing with the new circumstances? Projects such as educational vouchers and a standardized computer-graded test, intended to reduce corruption, have been highly controversial, and the vouchers failed completely. However, Osipian argues for continuing such initiatives (including vouchers, standardized tests and educational loans), as he believes they may represent a viable solution to the rampant corruption in education. He also favours further restructuring, decentralization and privatization of a system which is de facto already privatized.

Yin Cheong Cheng reflects on what he calls "the emerging syndrome of educational reform" across the Asia-Pacific region. He shows how the overabundance of reforms and initiatives in the last 15 years has had a negative effect on teacher ecology and teacher management. Drawing on the lessons learnt from those failed reforms and a study on the world's best-performing educational systems (McKinsey \& Co. 2007), Cheng develops "a holistic approach to managing teachers and planning for their sustainable professional development". He observes paradigm shifts in educational reforms in the region, along with shifts in policy concerns and changes in educational demands-moving away from "traditional approaches that emphasize standardization, centralization, maintenance, and control, towards new approaches that involve diversification, decentralization, development, and personal initiative". All these changes, Cheng argues, play a significant role in developing appropriate strategies and methods for teacher management and in understanding the evolution of future educational reforms.

Esther Gottlieb's essay aims to capture the work and life of Rolland Paulston, a wholly distinctive voice in the field of comparative and international education. His work, based on earlier postmodern mapping contributions in geography and also in feminist, literary and post- colonialist studies, is a profound incursion into the intellectual history of comparative education. "Mapping", a fundamentally non-linear representational system, became for Paulston a new way of seeing spatial turns in humanities and social sciences. However, his writings go well beyond the borders of a simple postmodern exercise in virtuosity. His social cartography is a highly reflexive way to open the space for various knowledge perspectives and to promote "a useful visual and verbal dialogue" between "disputatious communities" (Paulston 2000). Thus, his work stands as an act of reflection, understanding, justice and liberation, and develops grounds for resistance. His writings are pervaded by a novel blend of ethics and courage.

Paulston was highly conscious of political, economic and social issues, as well as of cultural differences. Intensely aware of the ways "modernist orthodoxy" favoured a single, objective reality, he tried to make the borders of the comparative education field more porous, so as to include a multitude of realities and perspectives, which would allow ontological choices and knowledge debates. Paulston's work, along with his unique wit and encyclopedic knowledge, continue to greatly inspire both new and established scholars in comparative education.

The articles gathered in this issue of Prospects are indicative, following Paulston's thinking, of the partiality of one's story (indeed, of all stories, as Paulston would have put it), while adding, with authority and conviction, the authors' fresh, different views on those stories. They open the field of comparative education to new perspectives and debates.

Acknowledgments My special thanks to Simona Popa for her significant contribution to the writing of this editorial. 


\section{References}

McKinsey \& Co. (2007). How the world's best-performing school systems come out on top. <www. mckinsey.com/clientservice/socialsector/resources/pdf/Worlds_School_systems_final.pdf>.

Paulston, R. G. (2000). A spatial turn in comparative education? Constructing a social cartography of difference. In J. Schriewer (Ed.), Discourse formation in comparative education. Frankfurt, Germany: Peter Lang. 